\title{
Stimulation by gonococci of chloride ion uptake in human leucocytes in relation to other properties of phagocytosis
}

\author{
A. SUKHAN and G. M. WISEMAN
}

Department of Medical Microbiology, University of Manitoba Medical School, Winnipeg, Manitoba, Canada R3E OW3

\begin{abstract}
Summary. Human polymorphonuclear leucocytes (PMNL) underwent several changes in response to challenge with Neisseria gonorrhoeae, namely (1) an increase in oxygen uptake, (2) changes in membrane electrical properties, and (3) increased transport of chloride ions $\left(\mathrm{Cl}^{-}\right)$across the membrane. Mean oxygen consumption and $\mathrm{Cl}^{-}$uptake by PMNL were stimulated by both pilate $\left(\mathrm{P}^{+}\right)$and non-pilate $\left(\mathrm{P}^{-}\right)$gonococci, although the levels were much reduced in the presence of $\mathrm{P}^{+}$organisms. $\mathrm{P}^{+}$gonococci also initiated low levels of polarisation or depolarisation in contrast with $\mathrm{P}^{-}$cells, which caused hyperpolarisation followed by depolarisation in the PMNL. Most of the strains showed these patterns. High performance liquid chromatography of extracts of unstimulated PMNL and of PMNL challenged with gonococci confirmed production of hypochlorous acid (HOC1) in the leucocyte. Furthermore, addition of radiolabelled $\mathrm{Cl}^{-}$to the PMNLs showed that some of the $\mathrm{Cl}^{-}$taken up by the cells in response to gonococcal challenge was incorporated into the $\mathrm{HOCl}$, suggesting a direct relationship between stimulation of $\mathrm{Cl}^{-}$uptake and production of active chlorine compounds in the leucocyte.
\end{abstract}

\section{Introduction}

In previous work, ${ }^{1}$ it has been shown that the putative receptor in erythrocytes for pilate $\left(\mathrm{P}^{+}\right)$ Neisseria gonorrhoeae is band 3 protein, a transmembrane protein which mediates anion transport across the membrane. ${ }^{2}$ Wiseman et al. ${ }^{3}$ have also shown that $\mathrm{P}^{+}$gonococci associating with human erythrocytes alter chloride $\left(\mathrm{Cl}^{-}\right)$and chloride/bicarbonate exchange across the membrane, as measured with a $\mathrm{Cl}^{-}$ -sensitive electrode. Wiseman and Martin ${ }^{4}$ observed a number of similar changes with human leucocytes although a specific leucocyte receptor was not identified.

Polymorphonuclear leucocytes (PMNLs) undergo various changes when they interact with a foreign particle. These include membrane polarisation ${ }^{5}$ and several changes initiated by increased glycolysis. Initial energy is provided by the glycolytic pathway, ${ }^{6}$ but once a phagolysosome is formed, microbicidal effects are caused by the formation of toxic oxygen products $\left(\cdot \mathrm{O}_{2}{ }^{-}, \mathrm{H}_{2} \mathrm{O}_{2}, \cdot \mathrm{OH}, \mathrm{HOCl}\right.$, etc.) mediated by myeloperoxidase activity. ${ }^{7}$ The latter enzyme is an important component of PMNL microbicidal systems in conjunction with $\mathrm{I}^{-}$or $\mathrm{Cl}^{-}$, utilised as co-factors by PMNLs for the purpose of killing. ${ }^{8}$ The $\mathrm{I}^{-}$ iodinates proteins and $\mathrm{Cl}^{-}$may result in production of $\mathrm{HOCl}$ (hypochlorous acid) in the phagosome. Foote et al. ${ }^{9}$ have calculated that at least $28 \%$ of the oxygen taken up during the respiratory burst is converted to active chlorinating agents such as $\mathrm{HOCl}$ and the chloramines. No information is available on the source of the $\mathrm{Cl}^{-}$ions but they may originate from reserves in the PMNL. Klebanoff ${ }^{10}$ showed that $\mathrm{Cl}^{-}$ion concentration in PMNLs is high relative to other cells.

In the present study, we have examined the interaction of $\mathrm{P}^{+}$and $\mathrm{P}^{-}$pairs of gonococci with human PMNLs with particular reference to ingestion, oxygen uptake and transmembrane potential, all properties of PMNLs associated with phagocytosis. We have also explored the hypothesis generated from previous work that interaction of PMNLs with gonococci and other bacteria stimulates anion transport across the PMNL membrane. We have addressed the questions of whether PMNLs utilise only intracellular $\mathrm{Cl}^{-}$reserves in the production of hypochlorous acid, or use $\mathrm{Cl}^{-}$drawn into the phagocyte from without, and whether there are differences in $\mathrm{Cl}^{-}$ uptake by $\mathrm{P}^{+} / \mathbf{P}^{-}$(virulent/avirulent) pairs that might be associated with changes in phagocytosing cells referred to above.

\section{Materials and methods}

\section{Strains}

Nine $\mathrm{P}^{+}$and $\mathrm{P}^{-}$pairs of $N$. gonorrhoeae were used in this investigation. Each $\mathrm{P}^{+}$strain was isolated from a single patient. The $\mathrm{P}^{-}$variants (including the U-6

Received 15 Jan. 1990; revised version accepted 25 Sep. 1990. 
strain) arose from laboratory cultivation of the $\mathrm{P}^{+}$ strains. However, strains 191, 44269 and F-62 were laboratory strains held for several years and DC-1, DC-2, DC-4, DC-5 and LC-1 were very recent isolates supplied by the Health Sciences Centre Microbiology Laboratory. Strains U-6, LC-1 and DC-4 were used only for part of the study. All were stored in suspensions in skimmed milk at $-70^{\circ} \mathrm{C}$ until required. Two strains, DC-4 and LC-1, were used only in the investigation of transmembrane potential. The nine $\mathrm{P}^{+}$strains were originally isolated from urethral exudates of men and were assessed for the presence of pili by electronmicroscopy. Opacity and colonial morphology were determined with a Bausch and Lomb stereomicroscope with bottom and side illumination. Two of the nine strains, including the $\mathrm{P}^{-}$variants, 191 and F-62, were opacity-negative and the others were opacity-positive. Pilus-positive (pilate) strains were designated $\mathbf{P}^{+}$and opacity-positive strains were referred to as $\mathrm{O}^{+}$.

Stocks held at $-70^{\circ} \mathrm{C}$ were thawed at room temperature and plated on Gonococcus Agar Base (GCB; Baltimore Biological Laboratories). Isovitalex ${ }^{11}$ was added in a ratio of isovitalex to GCB $1: 50 \mathrm{v}: \mathrm{w}$. Cultures were incubated for $16-22 \mathrm{~h}$ in a hotpack $\mathrm{CO}_{2}$ incubator at $36^{\circ} \mathrm{C}$, with $95 \%$ relative humidity; $\mathrm{CO}_{2}$ concentration was $4 \%$.

\section{Reagents}

All reagents were analytical grade where possible. Inhibitors of anion transport, 4,4'-diisothiocyano-2, $2^{\prime}$ disulphonic acid stilbene (DIDS) and $\alpha$-cyano-4hydroxycinnamic acid $(\alpha-\mathrm{CHC})$ were purchased from Sigma Chemicals, St Louis, MO. The fluorescent dye 3,3'-dipropylthiadicarbocyanine iodide ( $\left.\mathrm{Di}-\mathrm{S}-\mathrm{C}_{3}[5]\right)$, used in the measurement of transmembrane potential, was obtained from Molecular Probes, Inc., Eugene, OR. Radiolabelled chloride supplied as $\mathrm{Na}^{36} \mathrm{Cl}$ was obtained from ICN, Montreal, Quebec, at a specific activity of $260-670 \mathrm{MBq} / \mathrm{g}$.

\section{Assessment of pilation}

Bacterial preparations were negatively stained with uranyl acetate on grids and examined by transmission electronmicroscopy at a magnification of 30000 .

\section{Preparation of PMNLs}

Blood from a volunteer was freshly drawn a few hours before the experiment. White cells were processed according to the procedure of Odumeru et al. ${ }^{12}$ Briefly, 1-8 tubes of blood were drawn with heparinised Vacutainers ${ }^{\mathbb{Q}}(\mathrm{BBL})$. A bout $2 \mathrm{ml}$ of dextran $6 \% \mathrm{w} /$ $\mathrm{v}$ in saline was added to each tube. Blood cells were allowed to sediment for 45-60 min with the tubes set at a $45^{\circ}$ angle. The supernate was removed and the cells were pelleted by centrifugation at $200 \mathrm{~g}$ for $10 \mathrm{~min}$. The cells were washed twice with heparinised saline, suspended in a solution of $\mathrm{NH}_{4} \mathrm{Cl} 0 \cdot 84 \% \mathrm{w} / \mathrm{v}$ in water and incubated at $37^{\circ} \mathrm{C}$ for $10 \mathrm{~min}$. The cells were again pelleted by centrifugation, washed and resuspended in appropriate suspending fluid-Hanks's Balanced Salts Solution (HBBS) or Proteose-Peptone saline (PPS), the latter consisting of Proteose-Peptone (Gibco) $1 \% \mathrm{w} / \mathrm{v}$ dissolved in $\mathrm{NaCl} 0.85 \% \mathrm{w} / \mathrm{v}$ in distilled water. PMNLs were tested for viability by trypan blue exclusion before each experiment and counted.

Blood from one individual was used for most of the experiments. Occasionally, other persons were used as donors. An experiment was performed in which the ${ }^{36} \mathrm{Cl}^{-}$uptake by PMNLs from several donors was compared (data not shown). Although there was some minor variation in results from person to person and even in the same individual from week to week, differences were not judged to be important. Because serum was used as a source of complement in some experiments, it was tested for antibody to Neisseria spp. and found to give negative results in a Western blotting procedure (see below). A positive control was also included in which patients' serum was known to contain antibody to $N$. gonorrhoeae.

\section{Outer membrane protein (OMP) analysis}

The method of Barenkamp et al. ${ }^{13}$ was used to obtain sarcosinate-insoluble OMP from $24 \mathrm{~h}$ cultures of $N$. gonorrhoeae strains. Proteins were dissolved at $100^{\circ} \mathrm{C}$ for $5 \mathrm{~min}$ in sodium dodecyl sulphate $2 \%$, glycerol $10 \%, 2$-mercaptoethanol $5 \%$ and $0.0625 \mathrm{M}$ Tris- $\mathrm{HCl}$ (pH 6.8). About $40 \mu \mathrm{g}$ of protein from each strain was analysed by sodium dodecyl sulphatepolyacrylamide gel electrophoresis (SDS-PAGE) in $12 \%$ gels ( $1.5 \mathrm{~mm}$ thick), as described by Studier. ${ }^{14}$

\section{Immunoblotting procedures}

Serum used as opsonin in these experiments was tested for the presence of antibodies to $N$. gonorrhoeae. Western blots of gonococcal OMP were blocked with bovine serum albumin $4 \%$, and then incubated with either test serum or serum known to contain gonococcus antibodies, for $60 \mathrm{~min}$ at $37^{\circ} \mathrm{C}$. Blots were washed with Tris (hydroxymethyl) aminomethane saline buffer, $\mathrm{pH} 7 \cdot 2$, and incubated with horseradish peroxidase-conjugated anti-human light and heavy chain antibody. Bands were visualised by rinsing blots in

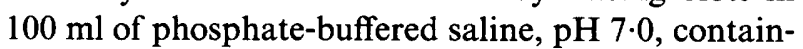
ing $100 \mu \mathrm{l}$ of hydrogen peroxide and $50 \mathrm{mg}$ of diaminobenzidine diamine.

\section{Uptake of $\mathrm{Na}^{36} \mathrm{Cl}$ by human PMNLs}

Uptake of radiolabelled chloride by PMNLs was performed with a modification of the rapid sampling technique of Hawkins and Berlin. ${ }^{15}$ Freshly prepared PMNLs (about $10^{5}$ cells) were pipetted on to circular $(10 \mathrm{~mm})$ glass coverslips and placed in a large 
moisture-containing petri dish $(150 \mathrm{~mm})$ at $37^{\circ} \mathrm{C}$. After $60 \mathrm{~min}$, at least $90 \%$ of PMNLs adhered to the glass. Excess fluid was removed from the coverslips and replaced with $100 \mu \mathrm{l}$ of PPS containing gonococci at a concentration of $10^{7} \mathrm{cfu} / \mathrm{ml}$. In some experiments, no organisms were added. The $\mathrm{Na}^{36} \mathrm{Cl}$ solution was added directly to the cover-slips at a concentration of $0.015 \mathrm{MBq}$. The dish was returned to the water bath and, at appropriate time intervals $(5,10,20$ and $30 \mathrm{~min}$ ), a coverslip was removed and passed through four washes of cold PPS or HBSS. This was effective in removing extracellular label. The coverslip was placed in a counting vial and PMNLs were lysed by treatment with $0.5 \mathrm{M} \mathrm{KOH}$ for $30-60 \mathrm{~min}$ at $37^{\circ} \mathrm{C}$ and neutralised with $0.5 \mathrm{M} \mathrm{HCl}$, to $\mathrm{pH} 7 \cdot 0$, before addition of $5 \mathrm{ml}$ of scintillant. The activity was then read in an LKB liquid scintillation counter (model 1215 Rackbeta II). In some experiments, anion transport inhibitors, DIDS or $\alpha-\mathrm{CHC}$, were added to the adherent PMNLs $5 \mathrm{~min}$ before the addition of the radiolabel.

\section{Phagocytosis assay}

This assay was performed as described elsewhere ${ }^{12}$ and was based on acridine orange labelling of the bacteria, which fluoresce green or red when examined by ultraviolet microscopy, depending on viability. The ratio of bacteria to PMNLs was $100: 1$, and coverslips with adherent PMNLs were incubated for 15-min intervals up to $1 \mathrm{~h}$. At each time interval, they were stained with the dye, washed and flooded with crystal violet. This latter dye quenched fluorescence of extracellular bacteria. After one further washing, coverslips were placed on a glass slide (cells down) and examined with a Leitz UV epiluminescence microscope. One hundred PMNLs were counted and the total intracellular count (including viable and dead gonococci) was recorded. The experiment was repeated once.

\section{Oxygen consumption by PMNLs}

Oxygen consumption in freshly drawn PMNLs was measured in the YSI model 5300 Biological Oxygen Monitor (Yellow Springs Instrument Co., Yellow Springs, OH, USA) equipped with standard bath assembly and two Clark oxygen sensors. The bath assembly, samples and sensors were kept at $37^{\circ} \mathrm{C}$ throughout an experiment by connection to a Haake model FE2 circulating water bath. At the beginning of an experiment, the oxygen sensors were calibrated with air-saturated distilled water. PPS ( $3 \mathrm{ml})$ containing $\left(5 \times 10^{5}\right)-\left(1 \times 10^{6}\right) \mathrm{PMNL} / \mathrm{ml}$, gonococci at a ratio of gonococci : PMNL 100:1, and normal human serum $(20 \mu \mathrm{l} / \mathrm{ml})$ were placed in the chamber and the sensor was inserted. One chamber contained PMNLs and serum (the control) and the other PMNLs, gonococci and serum. The suspensions were stirred constantly at a uniform rate by magnetic stirring bars. Oxygen levels were monitored every few minutes until one of the readings for the two chambers reached zero. Data were converted to be read as $\mu$ l of oxygen consumed. An oxygen uptake value measured at $30 \mathrm{~min}$ was used in comparison of strains.

\section{Transmembrane potential in PMNLs}

Transmembrane potential was determined by the method of Lyman et al. ${ }^{16}$ and was measured in the presence of the fluorescent dye $\mathrm{Di}-\mathrm{S}-\mathrm{C}_{3}$ [5] in an Aminco-Bowman spectro-fluorimeter. The exciting and emitting wavelengths were set at 620 and $670 \mathrm{~nm}$ respectively. The procedure was as follows: $1 \mathrm{ml}$ of $0 \cdot 1 \mathrm{M}$ HEPES buffered HBSS containing $10^{-6} \mathrm{M}$ dye and PMNLs $10^{6} / \mathrm{ml}$ was placed in a cuvette and fluorescence allowed to stabilise for $6-8 \mathrm{~min}$ at $37^{\circ} \mathrm{C}$. At this point, $10 \mu \mathrm{l}$ of solution was removed and replaced with $10 \mu \mathrm{l}$ of gonococci $\left(\mathrm{P}^{+}\right.$or $\left.\mathrm{P}^{-}\right)$suspended in serum. The suspensions of organisms were prepared by mixing $180 \mu \mathrm{l}$ of gonococci $\left(4 \times 10^{9} \mathrm{cfu} / \mathrm{ml}\right)$ with $20 \mu \mathrm{l}$ of normal human serum. With frequent stirring to avoid settling of cells, readings were taken at $670 \mathrm{~nm}$ at constant temperature. The blank used in these experiments was dye dissolved in HEPESHBSS. Data were plotted as fluorescence units (percentage transmission) against time. A fluorescence value measured at $20 \mathrm{~min}$ was used in the comparison of strains.

\section{HPLC (high performance liquid chromatography) methods}

PMNLs were prepared as previously described and suspended in buffer at a concentration $(0.5-5) \times 10^{6} / \mathrm{ml}$ as appropriate. The cells were rotated slowly on a Labquake shaker (Lab Industries, Berkely, CA 94710, USA) at $37^{\circ} \mathrm{C}$ for 30 or $90 \mathrm{~min}$ as required. Test suspensions of PMNLs were stimulated with gonococci $\left(10^{7} \mathrm{cfu} / \mathrm{ml}\right)$ and normal human serum $2 \%$ as opsonin. Test and control suspensions contained trimethoxybenzene (TMB), $100 \mu \mathrm{g} / \mathrm{ml}$, as the $\mathrm{Cl}^{-}$-ioncapture compound.

After rotary mixing, the cells were lysed by sonication, allowed to stand for $10 \mathrm{~min}$ at room temperature, and sodium thiosulphate was added in excess (about $2 \mathrm{~g}$ ). Following this, the lysate was passed through a Waters $\mathrm{C}_{18}$ Sep-Pak (Waters Associates, Milford, MA, 01757, USA) cartridge and was then extracted with $6 \mathrm{ml}$ of water and $6 \mathrm{ml}$ of methanol. The methanol fraction was evaporated and resuspended in $100-200 \mu 1$ of methanol. This was filtered through a Millipore $\mathrm{HU}(0.45 \mu \mathrm{m})$ syringe filter and $25-50 \mu 1$ of sample was injected into the HPLC system.

The HPLC pump (Waters M-45) was operated at a constant flow rate of $0.7 \mathrm{ml} / \mathrm{min}$. The mobile phase was a solution of equal parts of acetonitrile and double-distilled water. The stationary phase was an Alltech Econosil $C_{18} 5-\mu \mathrm{m}$ column (Alltech Associates 
Inc., Deerfield, IL 60015, USA) and detection was with a Shimadzu SPD-2A UV detector (Shimadzu Corp., Tokyo 160, Japan). The sensitivity of the detector was set at either 0.02 or 0.32 at $216 \mathrm{~nm}$. The sample was injected into the system and 2-min (1.4-ml volume) fractions were collected for $30 \mathrm{~min}$. The scintillation cocktail, when required, was added to each fraction in 5-ml volumes and analysed for radiolabel in the LKB Rackbeta II liquid scintillation counter in some experiments.

\section{Results}

\section{SDS-PAGE patterns of gonococcus strains used in the study}

Fig. 1 shows the SDS-PAGE Coomassie Bluestained profiles of the gonococcus strains. The patterns are characteristic of gonococcal OMPs, with a prominent band at about $36 \mathrm{Kda}$ attributed to protein- 1 (Por). All strains showed protein-3 (RMP), just below protein-1, but protein-2 (30-32 Kda) was not discernible in extracts of strains F-62 $\mathrm{P}^{+}$and $\mathrm{P}^{-}$, or DC-1 $\mathrm{P}^{-}$ (lanes B, C and E). All other strains appeared to contain protein- 2 in varying amounts.

\section{Oxygen uptake by stimulated PMNLs}

Oxygen uptake in human PMNLs challenged with gonococci was studied in a number of strains; results obtained with two strains are shown in fig. 2 . With strains DC-2 $\mathrm{P}^{+}, \mathrm{P}^{-}$and $44269 \mathrm{P}^{+}$(figs. 2A, 2C and $2 \mathrm{D}$ respectively), oxygen consumption by PMNLs in the presence of the organisms was increased in relation to the control. One strain, $44269 \mathrm{P}^{-}$(fig. 2B) showed the reverse relationship, uptake in the presence of the organisms being much less compared to the control. Consumption values at $30 \mathrm{~min}$ for these and other strains are given in table $\mathrm{I}$.

\section{Radiolabelled $\mathrm{Cl}^{-}$uptake by PMNLs}

In fig. 3, the mean of three experiments is shown in which unstimulated human PMNLs were incubated with $\mathrm{Na}^{36} \mathrm{Cl}$ buffered solution. Results show two peaks of uptake of label, one at about $3 \mathrm{~min}$ and the other at $20 \mathrm{~min}$, followed by a decline in intracellular label. Occasionally, the two peaks at 3 and $20 \mathrm{~min}$ were shifted to the right by about $2 \mathrm{~min}$. The overall pattern was, however, the same.

Fig. 4A shows that strain DC-2 $\mathrm{P}^{-}$stimulated $\mathrm{Cl}^{-}$ uptake in PMNLs in relation to the control and depressed it in the presence of $\mathbf{P}^{+}$cells. With strain 44269 (fig. 4B), $\mathrm{P}^{-}$organisms had a pattern of consumption close to that of the control PMNL suspension, but the uptake was stimulated at 20 and $30 \mathrm{~min}$. In contrast, the $\mathrm{P}^{+}$strain stimulated a larger uptake in PMNLs. Ratios for $\mathrm{Cl}^{-}$uptake by PMNLs incubated with DC- $2 \mathrm{P}^{+}$organisms were 0.87 and for $\mathrm{P}^{-}, 1 \cdot 16$, respectively, at $20 \mathrm{~min}$. For strain 44269 , they were $1.06\left(\mathrm{P}^{+}\right)$and $1.03\left(\mathrm{P}^{-}\right)$. Comparative ratios $\left(\mathrm{P}^{+}\right.$or $\mathrm{P}^{-} /$control $\left.\mathrm{PMNL}\right)$ are also given in table $\mathrm{I}$.

\section{Effect of inhibitors on uptake of radiolabelled $\mathrm{Cl}^{-}$ by $P M N L s$}

Anion transport inhibitors DIDS and $\alpha-\mathrm{CHC}$ (8$\left.32 \times 10^{-4} \mathrm{M}\right)$ were added to adherent PMNLs on

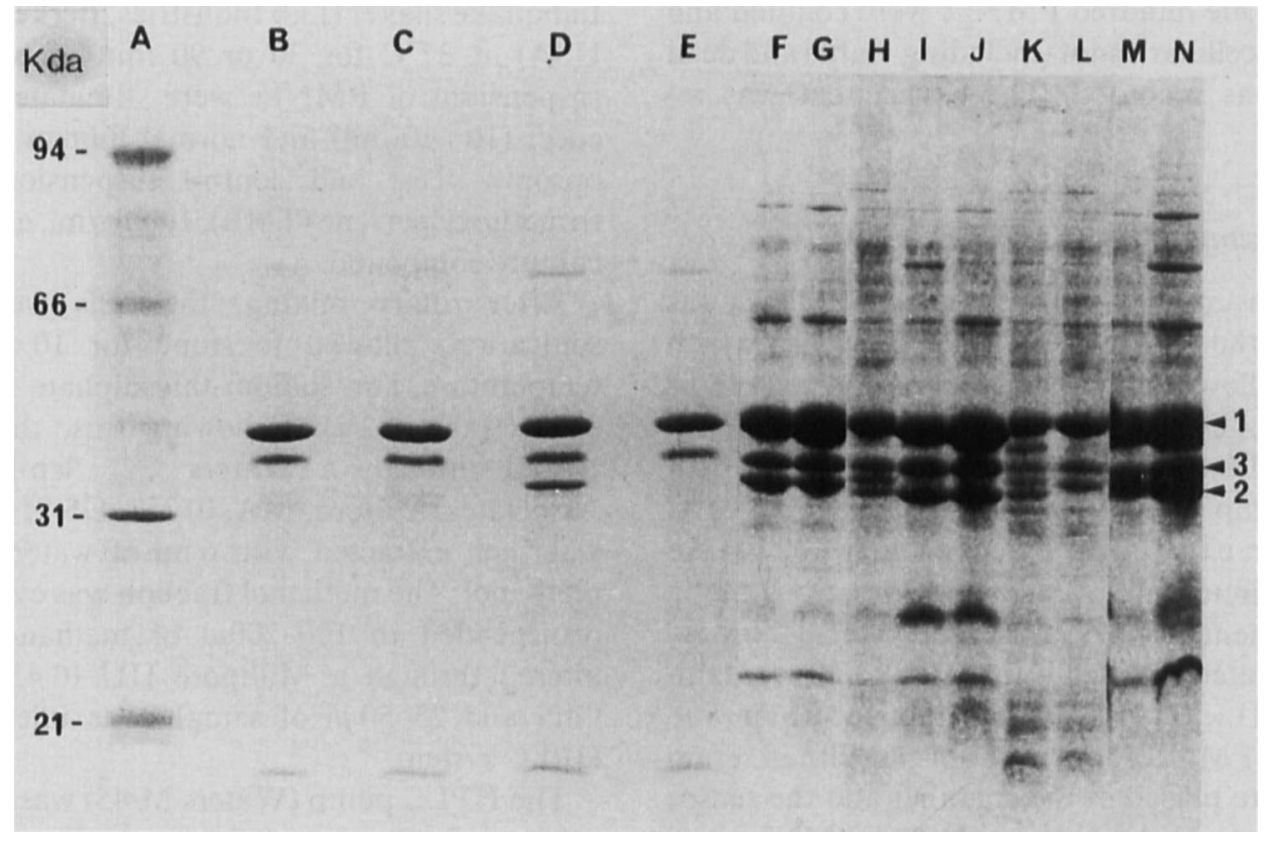

Fig. 1. SDS-PAGE of Coomassie Blue-stained OMPs of gonococcal strains. Lane $\mathbf{A}$, mol wt standards; $\mathbf{B}-\mathbf{E}$, strains F-62 $\mathbf{P}^{+}, \mathbf{P}^{-}, \mathbf{D C}^{-1} \mathbf{P}^{+}$ and $\mathbf{P}^{-} ; \mathbf{F}-\mathbf{H}$, strains $191 \mathbf{P}^{+}, \mathbf{P}^{-}$, and U6 $\mathbf{P}^{-}$; lanes $\mathbf{I}-\mathbf{N}$, strains DC-5 $\mathbf{P}^{+}, \mathbf{P}^{-}, 44269 \mathbf{P}^{+}, \mathbf{P}^{-}$, and DC-2 $\mathbf{P}^{+}, \mathbf{P}^{-}$. All strains were $\mathrm{O}^{+}$except F-62 and 191, which were $\mathrm{O}^{-}$. Proteins-1, 2 and 3 are marked on the right. Strains F-62 and DC-1 were tested at a different time from strains represented in lanes $\mathrm{F}-\mathrm{N}$ but are shown to the same scale. 


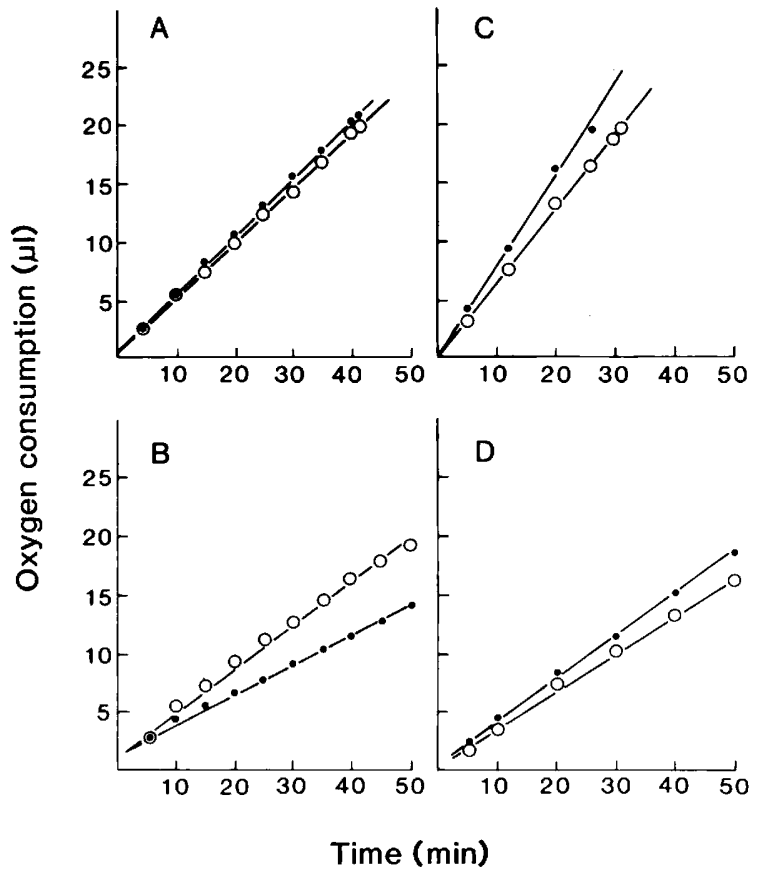

Fig. 2. Oxygen consumption in PMNLs challenged with $\mathrm{P}^{+}$and $\mathrm{P}^{-}$ gonococci : (A) strain $44269 \mathrm{P}^{+}$; (B) $44269 \mathrm{P}^{-}$; (C) DC-2 $\mathrm{P}^{+}$; and (D) DC-2 $\mathrm{P}^{-}(-$, test; $\mathrm{O}-\mathrm{O}$, control $)$.
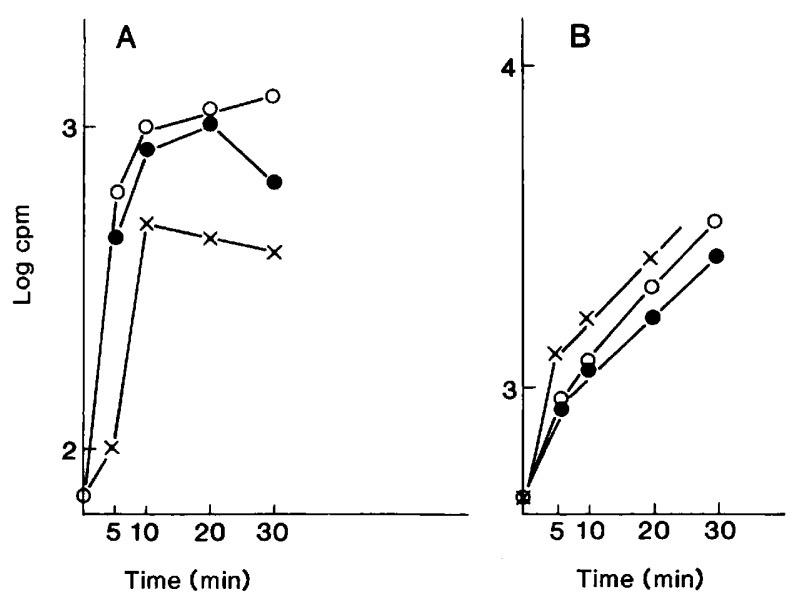

Fig. 4. ${ }^{36} \mathrm{Cl}^{-}$uptake by PMNLs in the presence of gonococcal strains DC-2 (A) and 44269 (B): $\mathrm{O}-\mathrm{O}, \mathrm{P}^{-} ; \times \stackrel{\times}{-} \times \mathrm{P}^{+}$; - - control.

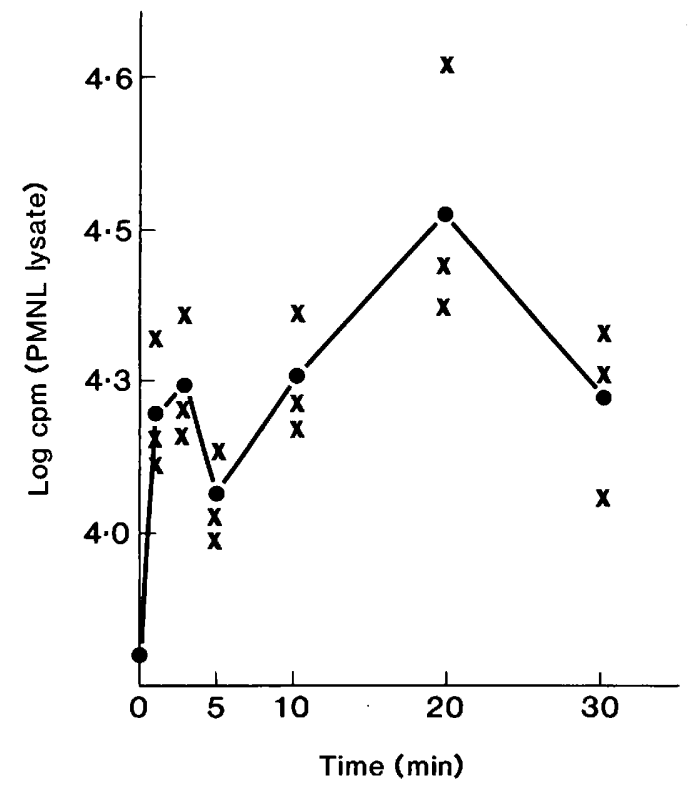

Fig. $3 .{ }^{36} \mathrm{Cl}^{-}$uptake by PMNLs; mean of three experiments.

coverslips before the addition of $\mathrm{Na}^{36} \mathrm{Cl}$ as previously described. Viability of PMNLs was unaffected by the inhibitors as indicated by trypan blue exclusion (not shown). Results (table II) show that maximum inhibition was about $82 \%$ for DIDS and $70 \%$ for $\alpha$-CHC at a concentration of $16 \times 10^{-4} \mathrm{M}$ and $32 \times 10^{-4} \mathrm{M}$, respectively.

\section{PMNL transmembrane potential in the presence of gonococci}

Fig. 5 shows that, in the presence of the dye Di-S$\mathrm{C}_{3}$ [5], PMNLs showed little or no depolarisation (as measured by fluorescence intensity or percentage transmission) when interacting with $\mathbf{P}^{+}$gonococci. Technically, the phenomenon observed is hyperpolarisation. The only exception in the $\mathbf{P}^{+}$group of strains was with PMNLs challenged with strain 44269 . By contrast, $\mathrm{P}^{-}$strains DC-4, 191, LC-1 and DC-5 initiated a brief period of hyperpolarisation (maximum depression of fluorescence during 5-15 min) followed

Table I. Biological properties of human PMNLs in response to gonococci

\begin{tabular}{|c|c|c|c|c|c|c|c|c|c|}
\hline \multirow{2}{*}{ Strain no. } & \multirow[b]{2}{*}{ Opacity } & \multicolumn{2}{|c|}{ Percentage phagocytosis } & \multicolumn{2}{|c|}{$\begin{array}{c}\text { Uptake of }{ }^{36} \mathrm{Cl}^{-*} \text { by } \\
\text { PMNL }\end{array}$} & \multicolumn{2}{|c|}{$\begin{array}{c}\text { Uptake of oxygen }{ }^{\dagger} \text { by } \\
\text { PMNL }\end{array}$} & \multicolumn{2}{|c|}{$\begin{array}{c}\text { Transmembrane } \\
\text { potential } \\
\end{array}$} \\
\hline & & $\mathbf{P}^{+}$ & $\mathbf{P}^{-}$ & $\mathrm{P}^{+}$ & $\mathbf{P}^{-}$ & $\mathrm{P}^{+}$ & $\mathbf{P}^{-}$ & $\mathbf{P}^{+}$ & $\mathbf{P}^{-}$ \\
\hline F-62 & - & 36 & 52 & $1 \cdot 04$ & $1 \cdot 29$ & $-1 \cdot 2$ & $1 \cdot 2$ & $-2 \cdot 85$ & $3 \cdot 17$ \\
\hline 191 & - & 30 & 60 & 0.96 & $1 \cdot 35$ & $1 \cdot 3$ & 1.5 & $-3 \cdot 0$ & $3 \cdot 0$ \\
\hline DC-2 & + & 24 & 37 & 0.87 & $1 \cdot 16$ & $4 \cdot 0$ & 1.9 & $-3 \cdot 8$ & $-1 \cdot 5$ \\
\hline 44269 & + & 20 & 32 & $1 \cdot 06$ & 1.03 & $1 \cdot 1$ & $-3 \cdot 5$ & 3.9 & $-2 \cdot 2$ \\
\hline DC-5 & + & 30 & 34 & $2 \cdot 08$ & $7 \cdot 17$ & 1.0 & $1 \cdot 5$ & $-5 \cdot 5$ & $2 \cdot 75$ \\
\hline DC-1 & + & 37 & 53 & $1 \cdot 38$ & 1.43 & $-5 \cdot 0$ & $5 \cdot 0$ & $\ldots$ & $\ldots$ \\
\hline Mean (SE) values & $\ldots$ & $29 \cdot 5(2 \cdot 7)$ & $44 \cdot 7(4 \cdot 8)$ & $1 \cdot 23(0 \cdot 18)$ & $2.24(0.99)$ & $0 \cdot 2(1 \cdot 2)$ & $1 \cdot 3(1 \cdot 1)$ & $-2 \cdot 27(1 \cdot 59)$ & $1.04(1.19)$ \\
\hline
\end{tabular}

* Ratios determined after $20 \mathrm{~min}$.

$†$ Differences from control measured after $30 \mathrm{~min}$; (-) denotes test value $<$ control.

$\ddagger$ Fluorescence units measured after $20 \mathrm{~min}$; $(-)$ denotes test value < control (polarisation). 
Table II. Effect of anion transport inhibitors on uptake of ${ }^{36} \mathrm{Cl}^{-}\left(\mathrm{Na}{ }^{36} \mathrm{Cl}\right)$ by human PMNLs

\begin{tabular}{|c|c|c|c|c|c|}
\hline \multirow{2}{*}{$\begin{array}{l}\text { Inhibitor } \\
\text { concentration } \\
\text { (M) }\end{array}$} & \multicolumn{3}{|c|}{$\begin{array}{l}\text { Intracellular cpm in } \\
\text { PMNLs after } 20 \mathrm{~min}\end{array}$} & \multicolumn{2}{|c|}{$\begin{array}{l}\text { Percentage } \\
\text { inhibition by }\end{array}$} \\
\hline & Control & DIDS & $\alpha-\mathrm{CHC}$ & DIDS & $\alpha-\mathrm{CHC}$ \\
\hline $\begin{array}{r}8 \times 10^{-4} \\
16 \times 10^{-4} \\
32 \times 10^{-4}\end{array}$ & $\begin{array}{c}5761 \\
18240 \\
7810\end{array}$ & $\begin{array}{l}4472 \\
3193 \\
6598\end{array}$ & $\begin{array}{c}5405 \\
11049 \\
2336\end{array}$ & $\begin{array}{l}28 \\
82 \\
16\end{array}$ & $\begin{array}{c}6 \\
39 \\
70\end{array}$ \\
\hline
\end{tabular}

by depolarisation reaching a maximum at 20-30 min. Strain F-62 $\mathrm{P}^{-}$caused depolarisation immediately, and strains DC-2 and $44269 \mathrm{P}^{-}$resembled $\mathrm{P}^{+}$strains generally.

The oxygen consumption characteristics induced by strains 44269 and F-62 showed the same kind of divergence as the transmembrane potential patterns (table I). However, with strains DC-5 and 191, oxygen consumption was stimulated in the presence of both $\mathbf{P}^{+}$and $\mathbf{P}^{-}$strains, but to a greater extent with $\mathbf{P}^{-}$, in contrast with their depolarisation patterns in which the $\mathrm{P}^{+}$strains caused little or no depolarisation. With strain $\mathrm{DC}-2$, neither $\mathrm{P}^{+}$nor $\mathrm{P}^{-}$variants initiated significant depolarisation compared with their stimulation of oxygen uptake.

\section{Summary of PMNL behaviour in the presence of gonococcal pairs}

A comparison of uptake of ${ }^{36} \mathrm{Cl}^{-}$oxygen, and changes in transmembrane potential, with a visual

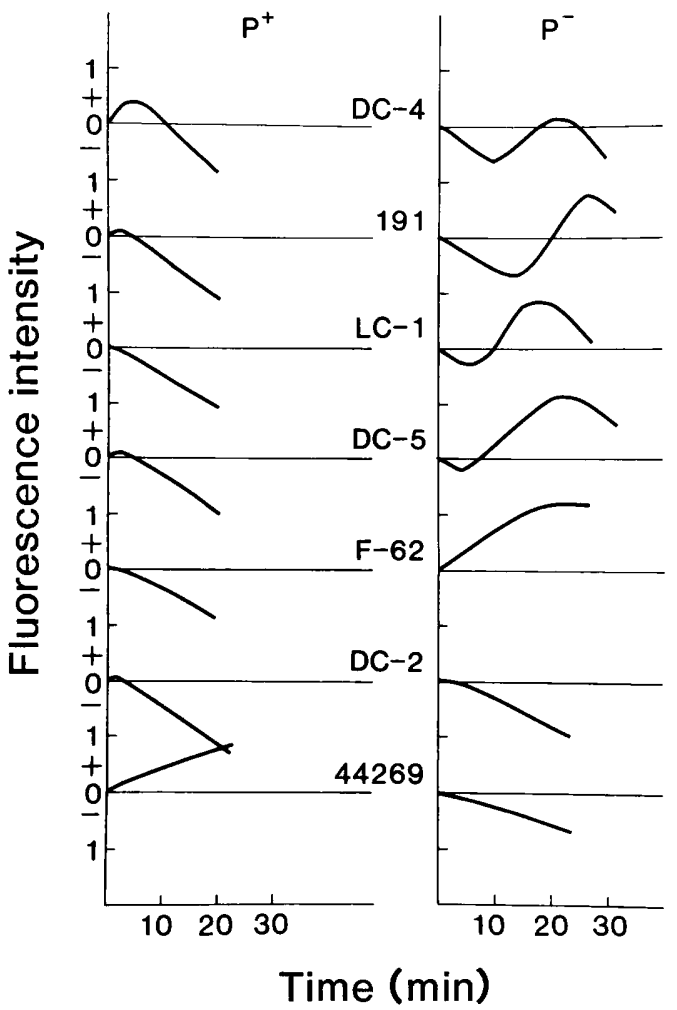

Fig. 5. PMNL transmembrane potential in the presence of gonococci. estimate of phagocytosis (acridine orange assay) is given in table $\mathrm{I}$. The data obtained from the acridine orange assay for $\mathrm{P}^{+}$and $\mathrm{P}^{-}$gonococci predictably indicated that the percentage phagocytosis was lower with the $\mathrm{P}^{+}$strains than with $\mathbf{P}^{-}$organisms. This serves as a reference point for the other data. All three indicators, ${ }^{36} \mathrm{Cl}^{-}$, oxygen uptake and transmembrane potential, show that when $\mathrm{P}^{+}$or $\mathrm{P}^{-}$group means were compared, activity of PMNLs ingesting $\mathrm{P}^{+}$organisms was quite different from that of those ingesting $\mathrm{P}^{-}$ cells. It should also be noted that while most $\mathrm{P}^{+}$and $\mathrm{P}^{-}$organisms stimulated ${ }^{36} \mathrm{Cl}^{-}$uptake above that for the controls, $\mathrm{P}^{+}$organisms caused less stimulation (mean uptake 1.23 for $\mathrm{P}^{+}$and 2.24 for $\mathrm{P}^{-}$cells). Oxygen consumption with $\mathbf{P}^{-}$cells was about six-fold greater than with $\mathrm{P}^{+}$strains, although both stimulated uptake. However, there were some differences between strains, e.g. negative values with strains $44269 \mathrm{P}^{-}$and F-62 $\mathrm{P}^{+}$and DC-1 $\mathrm{P}^{+}$. Transmembrane potential values were more negative (polarisation) in PMNLs ingesting $\mathbf{P}^{+}$organisms and more positive (indicating eventual depolarisation) with $\mathrm{P}^{-}$strains.

Student's $t$-test for unpaired data was used to compare mean values for $\mathrm{P}^{+}$and $\mathrm{P}^{-}$gonococci. As noted elsewhere, mean values obtained with $\mathrm{P}^{+}$ organisms were lower than those with $\mathrm{P}^{-}$cells ( $\mathrm{p}$ 0.010.025 ), and they correlated well with the acridine orange assay data. However, $p$ values of means for ${ }^{36} \mathrm{Cl}^{-}$uptake, oxygen consumption and transmembrane potential were $>0.1<0.2,>0.2<0.3$ and $>0.05<0.1$ respectively.

\section{Production of $\mathrm{HOCl}$ in PMNLs}

When PMNL extracts were analysed by HPLC, a few minor unidentified peaks were noted with the control extract (fig. 7A) which did not contain the $\mathrm{HOCl}$ trapping compound, TMB. The analysis of standard TMB and TMBCl dissolved in methanol $(100 \mu \mathrm{g} / \mathrm{ml})$ are shown in fig. 7B. Analysis of extracts of PMNL stimulated with strain U-6 $\mathrm{P}^{-}$showed two identifiable peaks, unreacted TMB and $\mathrm{TMBCl}$ formed by the reaction of TMB with $\mathrm{HOCl}$ in the PMNL. The naturally-produced $\mathrm{TMBCl}$ was not present in the control extract (fig. 7A). Unstimulated human PMNLs also chlorinated the added TMB, but the peaks were rather smaller that those obtained with PMNLs exposed to gonococci (data not shown).

Human PMNL suspensions challenged with strain U-6 were also incubated with $\mathrm{Na}^{36} \mathrm{Cl}$ solution and extracts were analysed by HPLC. Fig. 6 (mean of three separate experiments) shows that peaks of radioactivity were located in effluent volumes of $2 \cdot 8$, 9.8 and $14 \mathrm{ml}$. Standard TMBCl also appeared in a volume of $14 \mathrm{ml}$.

\section{Discussion}

In this study we have investigated two related questions. The first centred on the response of human 


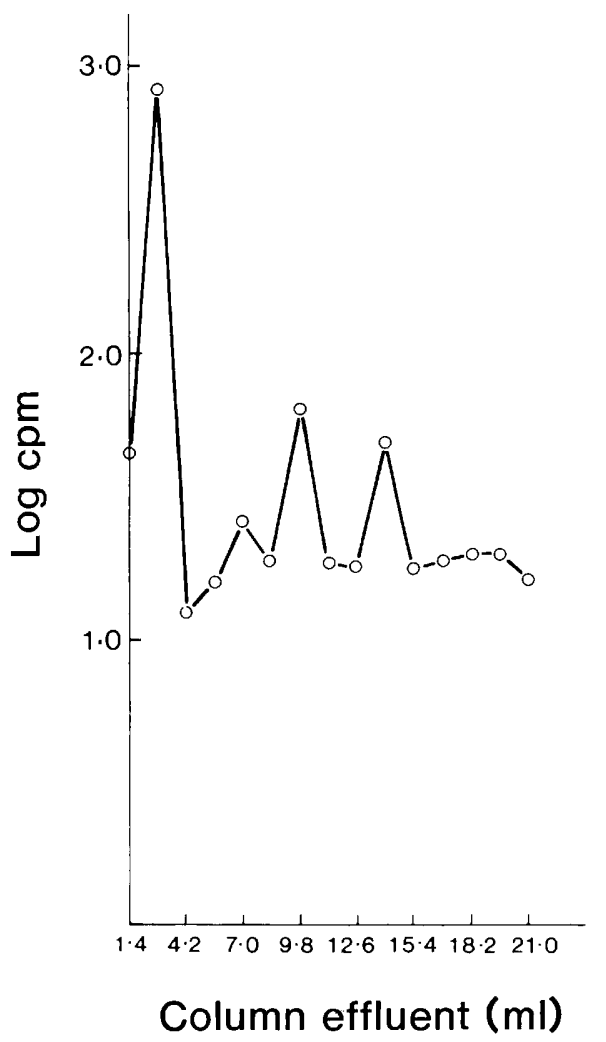

Fig. 6. Formation of ${ }^{36} \mathrm{Cl}^{-}$-labelled compounds in PMNLs challenged with gonococcal strain $\mathrm{U}-6 \mathrm{P}^{-}$. Radio-activity peak at $14 \mathrm{ml}$ corresponds to location of $\mathrm{TMBCl}$ standard.

PMNLs to $\mathrm{P}^{+}$and $\mathrm{P}^{-} N$. gonorrhoeae strains with reference to ingestion of bacteria, oxygen uptake and transmembrane potential. The central hypothesis was whether there were differences in the effect of $\mathrm{P}^{+}$and $\mathrm{P}^{-}$pairs of gonococci on these PMNL properties as a measure of virulence.

The second question focused on stimulation or inhibition of $\mathrm{Cl}^{-}$transport as a newly described phenomenon $^{3}$ associated with PMNLs in response to bacterial challenge. We wished to confirm earlier observations $^{9}$ that $\mathrm{HOCl}$ is formed within the PMNL as a microbicidal agent. We also wanted to establish whether $\mathrm{Cl}^{-}$anions are taken up from the cell's environment and used to manufacture $\mathrm{HOCl}$ as a result of bacterial challenge.

A test of the first hypothesis produced data which showed that uptake of oxygen and $\mathrm{Cl}^{-}$anions and changes in transmembrane potential differences in PMNLs in response to interaction with gonococci correlated with the phagocytic index (expressed as percentage phagocytosis). Generally, as would have been predicted, $\mathrm{P}^{+}$gonococci were more resistant to ingestion, but whereas both $\mathrm{P}^{+}$and $\mathrm{P}^{-}$pairs stimulated PMNL properties associated with phagocytosis, interaction with $\mathrm{P}^{+}$organisms caused less stimulation. It might be suggested that anomalous results obtained with a few strains (table I) were due to differences in protein-2, because Virji and Heckels ${ }^{17}$ observed in variants of their P9 strain that protein-2-expressing strains were killed intracellularly by PMNLs, and

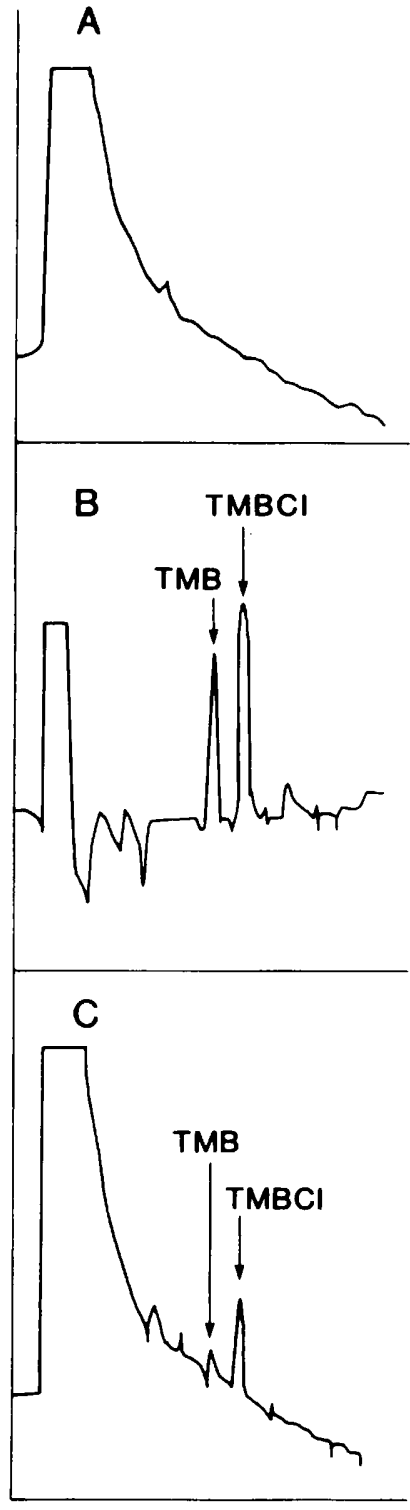

Fig. 7. HPLC profiles of PMNL extracts: (A) PMNL control; (B) methanol solution of TMB and TMBCl; (C) PMNL extract from cells challenged with strain U-6 $\mathrm{P}^{-}$. TMB is an uncombined compound originally added to PMNLs; TMBCl peak is produced by the PMNLs.

stimulated chemiluminescence, in contrast with strains in which protein- 2 was absent. In their opinion, protein-2 was more effective than pili in conditioning PMNL response. This view that OMPs may mediate interaction with PMNLs has also been offered by other authors. ${ }^{18-20}$ The data of Fischer and Rest ${ }^{20}$ suggest that the stimulatory effect of protein- 2 on chemiluminescence is dominant over that of pili. However, they felt that most, but not all, protein-2expressing strains mediate attachment, killing and chemiluminescence as a measure of the respiratory burst.

In the present study, we noted that strains F-62 $\left(\mathrm{P}^{+}\right.$ and $\left.\mathrm{P}^{-}\right)$and $\mathrm{DC}-1\left(\mathrm{P}^{-}\right)$appeared to express no protein-2, yet these strains showed characteristic properties no different from those of other protein-2expressing strains. Other strains that did not show 
characteristic differences between $\mathrm{P}^{+}$and $\mathrm{P}^{-}$variants (e.g., strain 44269) contained protein-2. We believe that our data indicated that pilation is more important in interactions of gonococci with PMNLs but we were dealing with six pairs of unrelated gonococcal strains (table I) in contrast with the several protein-2-positive and -negative variants of strain P9 of Virji and Heckels ${ }^{17}$ or the seven protein-2 variants of strain FA1090. ${ }^{20}$ Whatever the true nature of the interaction of gonococci with PMNLs, our observations suggest that $\mathrm{P}^{+}$organisms have a major effect on PMNL membrane activity as indicated by the low levels of polarisation/depolarisation noted in the presence of the organisms.

Data reported in our study have some parallel in other bacterial pathogens. Miller et al. ${ }^{21}$ observed that human PMNLs actively phagocytosing relatively avirulent strains of Staphylococcus aureus and Salmonella typhi exhibited greater oxygen uptake than control PMNLs. Introduction of a virulent strain inhibited the increased oxygen consumption seen during phagocytosis of avirulent organisms, which is similar to our findings with $\mathrm{P}^{+}$gonococci. Kossack et al. ${ }^{22}$ confirmed their observations in studies of PMNLs ingesting virulent and avirulent $S$. typhi strains. They found that virulent strains did not trigger the oxidative response (i.e., oxygen consumption and chemiluminescence) to the same extent as avirulent strains. Furthermore, Densen and Mandell ${ }^{23}$ observed that PMNLs ingesting $\mathrm{P}^{+}$gonococci in the presence of serum consumed oxygen at a slightly lower rate than those ingesting $\mathrm{P}^{-}$organisms. If serum was omitted, suspensions of PMNLs and $\mathrm{P}^{+}$cells consumed three times as much oxygen as PMNLs with $\mathrm{P}^{+}$cells. On the other hand, studies by Cohen and Cooney ${ }^{24}$ indicated that oxygen consumption by the bacteria themselves was stimulated by serum and that this might reduce oxygen available for microbicidal metabolism by PMNLs. In our study, the same human serum was added to all suspensions and whatever influence the presence of serum had on experimental conditions, it was expressed equally in all tests. Of the six pairs of gonococci we used, only one (strain 44269) failed to stimulate increased oxygen uptake compared to the PMNL control.

The second part of our investigation concerned transport of $\mathrm{Cl}^{-}$across PMNL membranes and whether bacterial contact with PMNLs induced increased uptake of the anion. We also examined whether ${ }^{36} \mathrm{Cl}^{-}$added to the test system was incorporated into $\mathrm{HOCl}$. Unstimulated PMNLs took up the radiolabel within the first few minutes of exposure. Contact with gonococci stimulated this uptake beyond the normal state in all but two of $12 \mathrm{P}^{+}$and $\mathrm{P}^{-}$ gonococci. Of the two exceptions (strains 191 and 44269 ) one was $\mathrm{O}^{-}$and both contained protein-2. We suggest that newly acquired $\mathrm{Cl}^{-}$co-factor is used to replenish the intracellular pool in the PMNLs and to generate $\mathrm{HOCl}$ anions in the presence of myeloperoxidase. Thus, PMNLs probably maintain a reserve of
$\mathrm{Cl}^{-}$for deployment as required. Klebanoff ${ }^{10}$ found that rabbit PMNLs contain about $75 \mathrm{mEq} / \mathrm{L}$ of $\mathrm{Cl}^{-}$, but a concentration of $0.5 \mathrm{mEq} / \mathrm{L}$ is all that is required for total bacterial killing by an isolated myeloperoxidase-halide system. In rabbits, therefore, there seems to be a large excess of $\mathrm{Cl}^{-}$anions, possibly constituting the intracellular pool we postulate for human PMNLs. We confirmed previous observations ${ }^{9}$ that $\mathrm{HOCl}$ is produced in the PMNL. Furthermore we obtained evidence that some of the radiolabelled $\mathrm{Cl}^{-}$was trapped by TMB, suggesting a direct relationship between stimulation of $\mathrm{Cl}^{-}$uptake and production of active chlorine compounds in the PMNL.

The question of ligands and receptors in the current investigation needs to be addressed. Earlier work ${ }^{1,3,4}$ indicated that erythrocyte band 3 was the putative receptor for gonococci interacting with erythrocytes resulting in haemagglutination. Evidence for this was: (1) pre-incubation of purified band 3 with gonococci inhibited gonococcus-erythrocyte haemagglutination; (2) $\mathrm{Cl}^{-}$anion exchange across erythrocyte membranes was altered in the presence of adherent organisms; and (3) known inhibitors of anion transport, DIDS and $\alpha-\mathrm{CHC}$, reduced haemagglutination titres and transport of $\mathrm{Cl}^{-}$across erythrocyte membranes. We have not specifically identified a receptor in human PMNLs, but some parallels may be drawn with the earlier work on erythrocytes. DIDS and $\alpha$-CHC also reduced $\mathrm{Cl}^{-}$transport in PMNLs in the present study (tableII). Since a small amount of serum was added to all experiments, it is possible that $\mathrm{C} 3 \mathrm{~b}, \mathrm{C} 3 \mathrm{bi}$ or $\mathrm{Fc}$ receptors on the PMNL are also associated with anion transport, which may explain our observations on uptake of ${ }^{36} \mathrm{Cl}^{-}$in stimulated PMNLs, or that attachment of gonococci through C3 fragments may interfere non-specifically with uptake. It is still unclear whether PMNL membranes contain a band 3-type of protein with properties identical to that in erythrocytes. Jessen et al. ${ }^{25}$ could not inhibit $\mathrm{Cl}^{-}$exchange in Ehrlich ascites cells with DIDS and found that ${ }^{3} \mathrm{H}-$ DIDS became bound to a $30-\mathrm{Kda}$ membrane protein, i.e., a protein with a molecular weight one third of that of band 3 protein.

None of the questions regarding the gonococcus ligand(s) involved in PMNL and other host-cell interactions has been resolved satisfactorily. Most investigators have ascribed a principal role to pili, but a substantial body of opinion points to the importance of protein-1 (Por) and protein-2 $2^{17-19,26}$ as prime components of interaction with host cells. It will be necessary to assess the effect of purified pili and proteins- 1 and -2 on PMNL properties or to use monoclonal antibodies to selected outer-membrane components before the real nature of molecular interactions between bacteria and PMNL is clarified.

This work was supported partly by the Manitoba Health Research Council and the Thorlakson Foundation. A.S. was in receipt of a stipend from the Department of Medical Microbiology. We also acknowledge the technical assistance of Mrs Linda Cressman for part of the study. 


\section{References}

1. Wiseman, GM. The nature of human erythrocyte receptors for Neisseria gonorrhoeae. Can J Microbiol 1982; 28: 219-222.

2. Steck TL. The band 3 protein of the human red cell membrane: a review. J Supramol Struct 1978; 8: 311-324.

3. Wiseman GM, Martin CF, McNicol PJ. Inhibition of anion transport in human erythrocytes by pilated Neisseria gonorrhoeae. Can J Microbiol 1984; 30: 52-56.

4. Wiseman GM, Martin CF. Changes in host cell membrane activities in response to adhesion of Neisseria gonorrhoeae. Can J Microbiol 1986; 32: 83-88

5. Ince C, Van Duijn B, Ypey DL, Van Bavel E, Weidema F, Leijh PCJ. Ionic channels and membrane hyperpolarization in human macrophages. J Membr Biol 1987; 97 : 251258.

6. Karnovsky ML. Metabolic basis of phagocytic activity. Physiol Rev 1962; 42: 143-168.

7. Spitznagel JK. Microbial interactions with neutrophils. Rev Infect Dis 1983; 55: 806-822.

8. Kreutzer DL, Dreyfus LA, Robertson DC. Interaction of polymorphonuclear leukocytes with smooth and rough strains of Brucella abortus. Infect Immun 1979; 23: 737-742.

9. Foote, CS, Goyne TE, Lehrer RI. Assessment of chlorination by human neutrophils. Nature 1983 ; 301 : 715-716.

10. Klebanoff SJ. Antimicrobial mechanisms in neutrophilic polymorphonuclear leukocytes. Semin Hematol 1975; 12: 117-142.

11. Martin, JE, Billings TE, Hackney JF, Thayer JD. Primary isolation of $N$. gonorrhoeae with a new commercial medium. Public Health Rep 1967; 82: 361.

12. Odumeru JA, Wiseman GM, Ronald AR. Virulence factors of Haemophilus ducreyi. Infect Immun 1984; 43: 607-611.

13. Barenkamp, SJ, Munson RS, Granoff GM. Subtyping isolates of Haemophilus influenzae type b by outer-membrane protein profiles. $J$ Infect Dis 1981 ; 143: 668-676.

14. Studier F. Analysis of bacteriophage T7 early RNAs and proteins on slab gels. J Mol Biol $1973 ; 79: 237-248$.

15. Hawkins RA, Berlin RD. Purine transport in polymorphonuclear leukocytes. Biochim Biophys Acta 1969; 173: 324-337.

16. Lyman CA, Simons ER, Melnick DA, Diamond RD. Unopson- ized Candida albicans hyphae stimulate a neutrophil respiratory burst and a cytosolic calcium flux without membrane depolarization. J Infect Dis 1987; 156: 770-776.

17. Virji M, Heckels JE. The effect of protein II and pili on the interaction of Neisseria gonorrhoeae with human polymorphonuclear leucocytes. J Gen Microbiol 1986; 132: 503512.

18. Britigan BE, Chai Y, Cohen MS. Metabolic, structural, and pathogenic changes of Neisseria gonorrhoeae exposed to human serum: an alternative view of the interaction between bacteria and the host. In: Schorlnik GK (ed) The pathogenic neisseria. Washington, DC, American Society for Microbiology 1985: 445-451.

19. Rest RF, Fischer SH, Ingham ZZ, Jones JF. Interactions of Neisseria gonorrhoeae with human neutrophils: effects of serum and gonococcal opacity on phagocyte killing and chemiluminescence. Infect Immun 1982; 36: 737-744.

20. Fischer SH, Rest RF. Gonococci possessing only certain P.II outer membrane proteins interact with human neutrophils. Infect Immun 1988; 56: 1574-1579.

21. Miller RM, Garbus J, Hornick RB. Lack of enhanced oxygen consumption by polymorphonuclear leukocytes on phagocytosis of virulent Salmonella typhi. Science 1972; 175: 1010-1011.

22. Kossack RE, Guerrant RL, Densen P, Shadelin J, Mandell GL. Diminished neutrophil oxidative metabolism after phagocytosis of virulent Salmonella typhi. Infect Immun $1981 ; 31$ : 674-678.

23. Densen P, Mandell GL. Gonococcal interactions with polymorphonuclear neutrophils. J Clin Invest 1978; 62: 1161-1171.

24. Cohen MS, Cooney MH. A bacterial respiratory burst: stimulation of metabolism of Neisseria gonorrhoeae by human serum. J Infect Dis 1984; 150 : 49-56.

25. Jessen F, Sjøholm C, Hoffman EK. Identification of the anion exchange protein of Ehrlich cells: a kinetic analysis of the inhibitory effects of 4,4'-diisothiocyano-2,2'-stilbene-disulfonic acid (DIDS) and labelling of membrane proteins with ${ }^{3}$ H-DIDS. J Membr Biol 1986; 92: 195-205.

26. Blake MS, Gotschlich EC. Gonococcal membrane proteins: speculation on their role in pathogenesis. Prog Allergy $1983 ; 33: 298-313$. 
